\title{
Archaeological heritage management in the Meuse valley (Limburg, the Netherlands) from a national perspective: aims, methods and results
}

\section{Eelco Rensink}

Cultural Heritage Agency of the Netherlands, Smallepad 5, 3811 MG Amersfoort, the Netherlands

Corresponding author. Email: e.rensink@cultureelerfgoed.nl

Manuscript received: 29 May 2016, accepted: 12 December 2016

\section{Abstract}

Numerous archaeological investigations have been performed along the river Meuse in the Netherlands' southeastern province of Limburg as part of the major 'Maaswerken' infrastructural project. To improve flood risk management and navigability, and for the purpose of gravel production and nature development, several areas of land covering a total of almost 2000 ha are being excavated to a great depth. In anticipation of this, archaeological research was performed for the purposes of recording and documenting archaeological remains in the most important areas and locations. From 1998 to 2015 the Cultural Heritage Agency of the Netherlands (Amersfoort) was in charge of the investigations, and acted as adviser to national public works agency Rijkswaterstaat.

The archaeological research connected with the Maaswerken project differed from regular, site-based investigations in terms of the landscape archaeology perspective on which it was based. The research themes and principles associated with this perspective were published in several documents, including a scientific policy plan published in 2004, and presented in further detail in area programmes and project briefs. The policy plan assigned each project area to one of five value assessment categories, based on the intactness of the landscape and the archaeological potential for addressing the research questions. In areas of high landscape intactness and great archaeological potential (category 1) the Agency selected zones to be surveyed and assessed, and for archaeological excavation. Though most of the fieldwork, including specialist analysis, was performed in these zones, other category project areas have also been the subject of archaeological fieldwork, including borehole surveys, site-oriented research and watching briefs, but on a more incidental basis. Observations were also made in the river Meuse itself and in the river's winter bed.

The archaeological investigations resulted in a large number of standard reports of desk studies and fieldwork, including reports of specialist analyses. A considerable proportion of these refer to the large-scale investigations at Borgharen and Itteren to the north of Maastricht, and at Lomm and Well-Aijen to the north of Venlo. The results of the investigations suggest the archaeological record here is rich and varied, with a time depth of c. 11,500 years, and traces of occupation and land use ranging from the Early Mesolithic (Well-Aijen, Borgharen) to the Second World War (Lomm).

This paper reflects on almost 20 years of archaeological research in the project areas of the Maaswerken and on the principles and methods used in the field research. The common thread is the results of landscape and archaeological studies and the relationship between them. Examples are used to illustrate results that can be regarded as important from a national perspective, and in terms of archaeological heritage management.

Keywords: archaeological heritage management, archaeology of national importance, landscape archaeology, methodology, Meuse valley, value assessment

\section{Introduction}

The province of Limburg is very important when it comes to researching the history of the Netherlands. Given its geographical location in the southeast of the country, much of it sandwiched between Germany and Belgium, Limburg has been a 'seedbed' for cultural developments and innovations that did not occur until later, if at all, in the other provinces of the Netherlands. It is the perfect place to study a number of interesting elements of the country's history (earliest occupation, Neolithisation, Romanisation). Not only does the province have a great wealth of finds, Limburg is also home to some unique sites that have defined Dutch archaeology. Examples include the early Neanderthal camps at Maastricht-Belvédère (Roebroeks, 
1988; De Loecker, 2005), the first agrarian settlements (Linear Bandkeramik) on the Graetheide Plateau (Van Wijk et al., 2014), the Middle Neolithic flint mines at Rijckholt (Rademakers, 1998; Deeben et al., 2011) and the Roman villa landscape between Maastricht and Aachen (Jeneson, 2013). Such groupings of archaeological sites have not been found anywhere else in the Netherlands. In view of the geographical location of Limburg, the adjacent regions of Belgium (Limburg, Liège) and Germany (North Rhine-Westphalia) define the foremost geographical framework for the study of these developments and innovations.

For a long time the focus of archaeological research in Limburg was the higher-lying terraces and coversand ridges in the sandy Pleistocene area of northern and central Limburg, and the loess-covered plateaus in the hills of southern Limburg. Until well into the 20th century the Holocene Meuse valley bottom was the setting for only a limited proportion of the archaeological research performed in the country. Though some excavations were carried out near Maastricht, Venlo and other towns (prior to the construction of new infrastructure, residential areas and industrial parks, for example), there were only reports of isolated finds from the vast majority of the Holocene Meuse valley. We had no clear picture of where people lived along the Meuse in prehistory and the early historic period, whether they had burial grounds and, if so, where, and what economic and ritual activities they engaged in.

That situation has now changed radically. Over the past 20 years numerous field projects conducted in the context of and according to the principles of development-led archaeology ('Malta archaeology') have been performed along the river Meuse in Limburg as part of the Maaswerken project. They include investigations at Borgharen and Itteren directly north of Maastricht, and further downriver at Lomm and Well-Aijen between Venlo and Nijmegen. These and other areas in the Maaswerken project are being (or have already been) excavated to a great depth to reduce the risk of river flooding and to improve navigability. This has been accompanied by the large-scale extraction of natural resources (sand and gravel) and nature development. Commercially unviable land has been returned to nature, with newly dug gullies and wildlife-friendly riverbanks. The earthworks have been such that large areas of the Holocene river landscape along the Meuse have been completely remodelled, and it has not been possible to preserve archaeological features and remains in situ.

This paper reflects on almost 20 years of archaeological research connected with the Maaswerken project. Between 1997 and 2000 several documents were written by the Project Team Archaeology focusing on the scientific goals and ambitions of the archaeological research. (The Project Team Archaeology under the direction of H. Stoepker had its seat in Maastricht after the signing in 1998 of a cooperation agreement for the Maaswerken project between Rijkswaterstaat and the Cultural Heritage Agency. The archaeological research of the Maaswerken project was also a school for knowledge acquisition and quality management in a large infrastructural project (see Stoepker \& Soeters, 2005; Stoepker, 2006b).) The first evaluation and synthesis was published in 2006 after completion of the prospections and evaluations (Stoepker, 2006a). Two years earlier, and partly based on the content of a scientific plan from 2000, a scientific policy plan (Stoepker et al., 2004) had been published, drafted by the Cultural Heritage Agency of the Netherlands (RCE) for the archaeology of the Maaswerken project. Now more than ten years after its publication in 2004, the time is ripe for a reexamination of a number of topics and questions in the policy plan. Have the archaeological objectives been achieved? Has the categorisation of the project areas proved worthwhile and workable? What have we learned about methods and techniques for prospective archaeological fieldwork? What new insights have the archaeological watching briefs given us? And how can we use the knowledge gained to improve archaeological heritage management in the Meuse valley in the future?

\section{Scientific principles}

As part of the evaluation of the archaeological value assessment and survey in the Maaswerken project (Stoepker, 2006a) the RCE drew up a scientific policy plan entitled 'Preservation and investigation of archaeological values in the Meuse valley in the context of the Maaswerken project and Via Limburg' (Stoepker et al., 2004). From 2004 this policy plan served as a guide and framework for the archaeological investigations. The document updated the archaeological objectives of the project on the basis of the data from the desk study and archaeological field survey available at the time, and reiterated the principles for the fieldwork (excavation). The project areas in the Maaswerken project were also assessed and classified according to their potential landscape and archaeological importance (see next section). It should be stressed that especially at the start of the Maaswerken project the Project Team Archaeology was facing a real challenge. At that time very little was known about the presence and nature of archaeological sites associated with primarily Holocene sediments in the valley floor of the river Meuse. Over the years this situation gradually improved thanks to the results of the prospections and assessments, demonstrating the archaeological richness of (specific parts of) the Meuse valley floor.

The common thread running through the policy plan is investigation from a landscape archaeology perspective. This is defined as 'combined archaeological, physical geographical, historical ecological and historical geographical research focused on the development, occupation and use of the cultural and physical landscape over the long term and the connection between these aspects of the landscape' (Stoepker et al., 2004: 15). In specific terms, the research focuses on the relationship between humans and the biotic and abiotic landscape, and the changes that have occurred from the earliest occupation to the 
Early Modern Period. The physical landscape is regarded as the changing - and therefore dynamic - backdrop to human activity, created by natural landscape-formation processes (sedimentation and erosion) and used, influenced and in some places radically altered by humans in the past. These archaeological objectives take account of two perspectives. The first is archaeological heritage management, with a focus on filling gaps in archaeological knowledge and developing field research methods specifically for river and stream valleys, for example. The second concerns humans and their behaviour and the long-term occupation and land use history of the Holocene Meuse valley. The archaeological record and the geological context of the archaeological remains and features provide the study material for both perspectives.

The overarching research themes included in the scientific policy plan were (Stoepker et al., 2004: 14):

1) development of the biotic and abiotic landscape;

2) the settlement system and infrastructure;

3) synchronous and diachronous relationships between landscape, occupation and other forms of landscape use;

4) the role of the Meuse and its distributaries as a source of power, a border, a source of food and a supplier of resources.

Besides these overarching research themes, specific themes and focal points were defined for each archaeological period (Stone Age, Metal Ages and Roman period, Middle Ages) (Stoepker et al., 2004: 43-46). The research themes and principles included in the scientific policy plan were worked out in more detail for certain project areas in the form of area programmes (De Loecker \& De Grooth, 2003; A. Simons et al., unpublished report, 2003; H. Stoepker \& J. Peeters, unpublished report, 2005) and project briefs.

\section{Value assessment classification}

The Maaswerken project is remarkable for the large number of areas involved (from Borgharen in the southern border area with Belgium (Grensmaas) to Well-Aijen to the north of Venray (Zandmaas)), the huge land areas to be excavated and the vast scale of the threat to the archaeological remains. The excavation of current and former banks and gullies of the Meuse river will impact on many hundreds of hectares of land, causing the irretrievable loss of large parts of a river landscape that was inhabited and used (sometimes intensively) by dozens of generations in the past. Partly for this reason, the RCE decided to apply a landscape archaeology perspective and take an area-based approach. This typically involves investigating archaeological features and remains (preferably as broad a range as possible) in relation to one another and to the surrounding landscape. A conscious decision was taken in this project not to focus on site-oriented investigation, with attention gradually narrowed down to a particular spot (known as the 'funnel model' in Dutch archaeology), which tends to result in the excavation of just one, or no more than a few, well-defined sites that warrant preservation, more or less separated from the surrounding landscape. (See the stages of the cycle of archaeological heritage management as described in the Dutch Archaeology Quality Standard (KNA).) In contrast to this site-oriented approach, fieldwork was mainly aimed at documenting and recording archaeological remains in different landscape zones in order to assess the archaeological characteristics and significance of these zones. In the approach adopted here, even areas 'devoid' of archaeology can be interesting subjects of study, as the absence of archaeological remains also requires an explanation. This procedure is in line with the objectives and principles of the scientific policy plan.

Given the decision to adopt a landscape archaeology perspective and take an area-based approach, over the years of the project archaeologists have collaborated closely with experts specialising in archaeological dating, physical geography, geology, archaeobotany, etc. Field excavation methods and techniques were coordinated as much as possible, and adapted and improved where possible.

Given the large area covered by the Maaswerken project and the expected differences in landscape and archaeological features, the RCE did not regard it as useful or feasible to investigate all areas in the same way and to the same extent. The areas were classified into five categories to allow well-considered choices of locations and methods for archaeological fieldwork. This classification was based on the intactness of the landscape and the potential archaeological and landscape importance. Five categories were defined (the areas were attributed to these five categories not only for the Maaswerken project areas but also for the route of the A73 motorway), and the project areas attributed to them as follows (Stoepker et al., 2004, 47-48):

category 1: high degree of landscape intactness and archaeological and landscape importance: Borgharen, Itteren, Nattenhoven, Lateraalkanaal-West, Ooijen, Lomm and Well-Aijen;

category 2: moderate or high archaeological importance, largely intact but less rare landscape: Aan de Meuse Zuid;

category 3: moderate archaeological importance and partially disturbed landscape: Hout-Blerick, Koeweide;

category 4: low archaeological importance in largely intact but less rare landscape: (A73 only);

category 5: low archaeological importance and landscape value: Grensmaas locations in recent floodplain, focus on nautical finds.

Large-scale archaeological investigations (excavations), including a large amount of specialist analysis (identification of material culture, dating, archaeobotanical analysis, physical geographical research, etc.) were performed mainly in category 1 areas, with the exception of Nattenhoven and Lateraalkanaal-West by Roermond, in connection with changes to the Maaswerken 
plans. Archaeological fieldwork in the other category areas was performed on a more incidental basis and partly aimed at the documentation of other types of finds and sites (e.g. nautical finds in category 5 areas) providing archaeological and landscape data complementary to those obtained from the category 1 areas.

\section{Fieldwork practice}

\section{Prospection}

At the start of the archaeological investigations in the Maaswerken project in the mid-1990s, the lack of information (certainly at the level of individual project areas) about the genesis, age and soil structure of the Holocene Meuse valley was a major knowledge gap. To improve the situation, it was initially decided that large-scale borehole campaigns on grids of $40 \times 30 \mathrm{~m}$ should be conducted (see e.g. Raemakers \& Heunks, 2000; Van Dijk, 2003). Properties of the soil were described for each individual borehole in accordance with a fixed system. This was used as a basis to verify and refine landscape maps (soil maps and geological maps, scale $1: 50,000$ ). The boreholes also served to trace and map locations (sites) or larger landscape zones containing archaeological material. By dating the archaeological material found in the cores, it was also possible to gain an initial impression of the minimum age of the sediments deposited by the Meuse river and the wind (river dunes). Various borehole surveys have been conducted in category 1, 2, 3 and 5 areas as mentioned in the previous section. These have made it clear that the lateral shift in and incision of the Meuse have had major implications for the erosion and preservation (sediment cover) of landscape zones and the physical condition of archaeological sites along the river.

Over time the procedure involving large-scale borehole surveys in grids of $40 \times 30 \mathrm{~m}$ was abandoned and the focus shifted to making boreholes in geo-archaeological sections perpendicular to geomorphological units. Long trenches were also dug to obtain cross-sections (e.g. Lomm phase 2: Gerrets \& De Leeuwe, 2011). Small inspection trenches were dug (Well-Aijen: Tichelman, 2005b) and profile columns documented. Combined with data from a borehole survey, such columns are ideal for establishing the presence, nature and depth of buried soils and/or archaeological levels.

In addition to the borehole survey, surface prospection was also conducted on fields with good surface visibility. These two methods yielded a large amount of archaeological material. It was not until later that the researchers began to realise that borehole surveys, in particular, are of limited value for the identification and interpretation of individual sites in the Holocene valley bottom of the Meuse. This became clear from the surveys in Borgharen, Lomm and Well-Aijen, where large zones defined and presented as 'findspots' are in fact landscape-geomorphological zones (or 'geomorphogenetic units') with compacted or scattered archaeological material. The results of the borehole survey are difficult to translate to discrete temporally and spatially defined archaeological sites. In the Holocene Meuse valley, archaeological sites do not contain any clear archaeological layers (cultural or occupation layers) that can be recognised with the naked eye. Certain types of site are therefore difficult or impossible to prospect using boreholes. Given these limitations, numerous trial trenches were dug primarily in category 1 areas (Borgharen and Itteren; Van de Graaf \& De Kramer, 2005a,b) in the southern Meuse valley. This also occurred in Lomm (Gerrets \& Williams, 2011) and Well-Aijen (Tichelman, 2005b; Bouma \& Müller, 2014; Kimenai \& Mooren, 2014) to the north of Venlo (Fig. 1). Notably, trial trenches were used as a method for performing large-scale surveys and value assessments in the defined landscape zones, rather than as a way of assessing the value of individual sites. In a few project areas, only site-oriented research was performed by digging trial trenches, for instance at the late prehistoric site 55 (Tichelman, 2005a) in the partially disturbed landscape of Trierveld near Koeweide (category 3).

\section{Selection of areas for archaeological excavation}

After the archaeological survey and value assessment, large parts of the category 1 areas were selected for archaeological excavation; some of them were even selected in their entirety, in line with the landscape archaeology perspective. One good example is the Lomm project area. This area, with a total surface area of $c .88$ ha, was regarded by the RCE as archaeologically important and valuable, a Siedlungskammer from late prehistory, and as such it was selected in its entirety for archaeological excavation. During the course of the excavations, which were performed in several phases, parts of the project area were deselected on the basis of interim findings, and were no longer eligible for excavation. The second example is Well-Aijen, section 2. This area of great archaeological importance contained around a dozen find concentrations (flint, stone, hazelnuts) from various phases of the Mesolithic, embedded in fine-grained Early and Middle Holocene flood sediments (point bar ridge) of the Meuse in close proximity and partially overlapping (Kimenai \& Mooren, 2014). The RCE selected the entire point bar ridge for excavation. Zones in this area were deselected during the course of the excavations (2012-2014).

\section{Archaeological excavation}

In accordance with the principles in the scientific policy plan, archaeological features and remains were documented as far as possible over large areas and as an integrated part of landscape zones (Rensink \& Vreenegoor, 2007). To ensure compliance with the area-based approach and landscape archaeology principles set out in the scientific policy plan, it was sometimes decided 


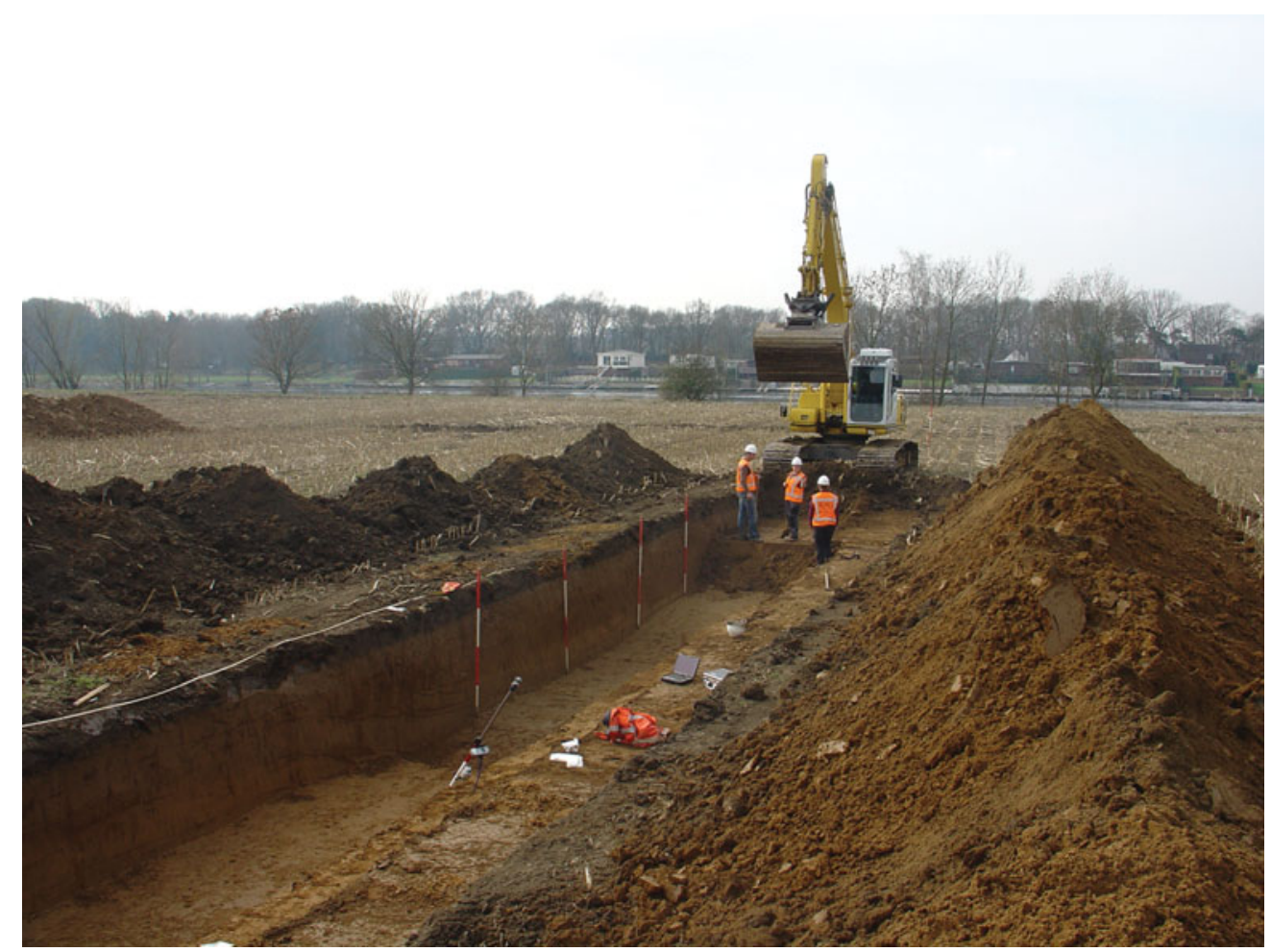

Fig. 1. One of the many trial trenches dug in Well-Aijen, section 2, summer 2011.

not to exhaustively document all the features of individual sites, such as flint sites or homesteads, unless they were of great archaeological importance ('national importance'; see 'Archaeology of national importance' section below).

The investigation at Well-Aijen, section 2 posed a great challenge. The large number of Mesolithic find concentrations spread over c. 2 ha and embedded in fine-grained Meuse point bar ridge deposits (see section below; Fig. 2), and an overlying Neolithic level on top of these deposits, meant decision-making and procedures in the field had to be both flexible and effective. The project brief had been drafted in such a way that it allowed a flexible response to new insights gained during the excavation. Though field research methods and techniques were mentioned in the project brief, there was plenty of scope to use them flexibly or to adapt them or add new methods and techniques to ensure the questions were properly addressed. Any additions to or deviations from the project brief were officially noted and approved in special memorandums.

Most of the samples for value assessment and further specialist analysis were collected during the excavation phase. OSL dating proved very important for establishing the dates of soil layers containing no archaeological finds and/or features.

\section{Archaeological watching briefs}

Last but not least, archaeological watching briefs constituted a large proportion of the archaeological research in the Maaswerken project. The principle was that during the imple- mentation phase, i.e. the large-scale machine removal of the surface layer, extensive observations would be made, preferably over a large area (Roymans, 2013). This mainly concerned project areas that were not selected for preventive archaeological investigation in the form of trial trench surveys and/or excavation. The fact that many hectares of partly buried archaeological landscapes along the Meuse would disappear for ever as a result of the digging operations made such extensive large-scale documentation desirable. The archaeological watching briefs focused mainly on the former sediment-filled Meuse gullies (Van der Gaauw \& Stassen, 2006). In the immediate vicinity of higher-lying occupation sites (settlements), one can expect to find waste-dumping zones, metal objects and remains of ships, fishing equipment, bridges, fords or jetties. The lowerlying, wetter sections of the Meuse valley are also potentially important locations for finding unburnt botanical and possibly also animal remains. Investigating and dating such remains allows conclusions to be drawn about the vegetation of the past and when and how humans influenced it (Zuidhoff \& Bos, 2016).

The archaeological watching briefs were part of the implementation phase, taking advantage of the opportunities afforded by the non-archaeological excavation works. Good arrangements with the contractor and strict safety requirements are very important. In spite of these requirements, however, watching briefs were performed in far from optimal conditions or were even cancelled due to safety risks, high water level or the rapidity of the commercial (mechanical) removal of the 


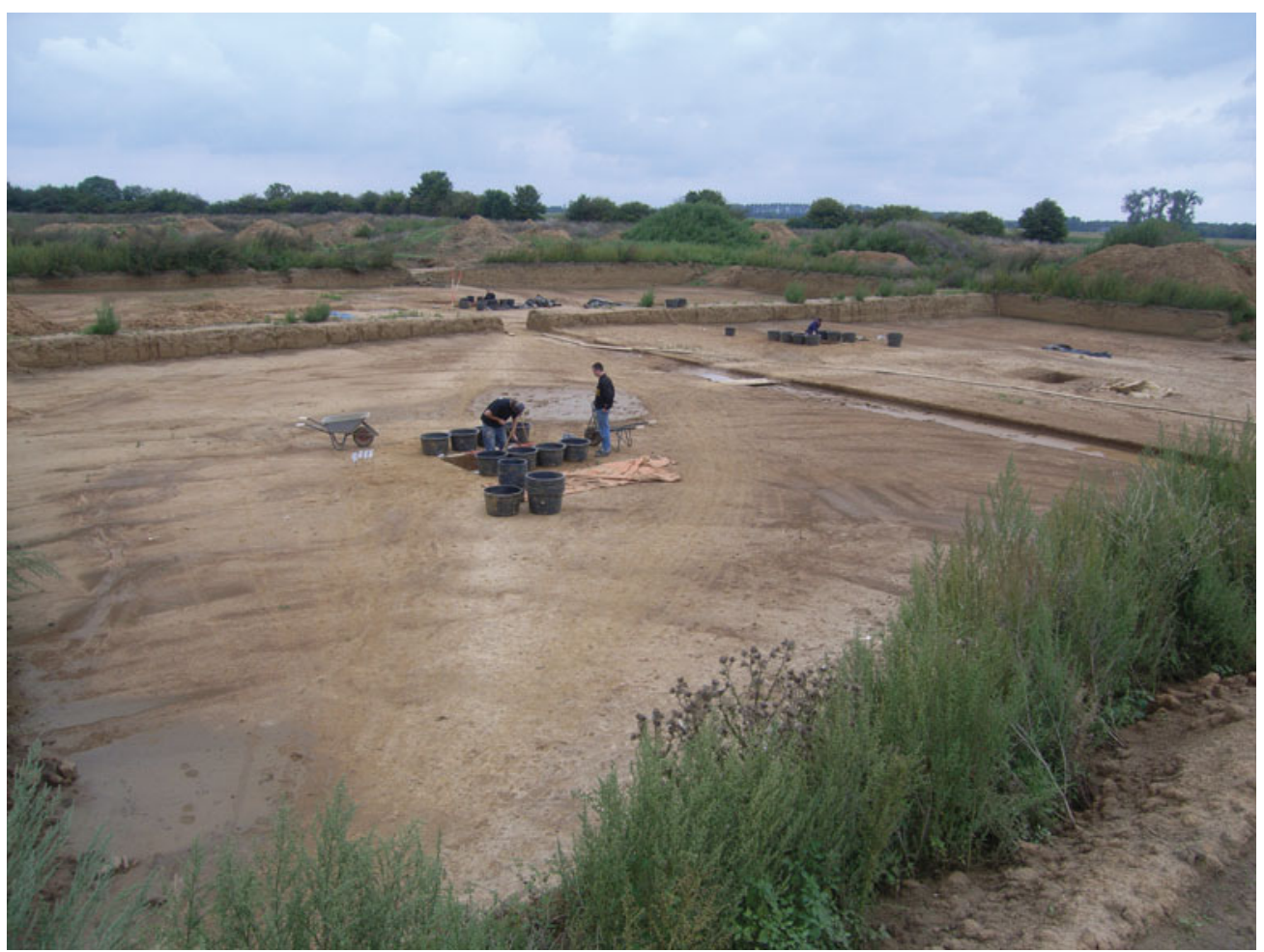

Fig. 2. Overview of the value assessment of a complete Mesolithic landscape containing numerous concentrations of stone artefacts at Well-Aijen, section 2, summer 2011 (excavation and photo: BAAC).

top soil. A new element of the watching briefs involved the huge Consortium Grensmaas sieving installations at Itteren. At this vast 'open-air factory' a large magnet filters iron from the gravel extracted during dredging work. (From 2014 to 2016, gravels and metal objects coming from three different project areas (Borgharen, Itteren, Aan de Maas Zuid) were processed and gathered respectively in the sieving installations at Itteren.) The iron passes down a gangway into a separate container. The archaeological consultancy RAAP gathered hundreds of (fragments of) swords, axes, boathooks, anchors, horseshoes, etc. (Fig. 3). Such objects are seldom found during archaeological excavations. They are therefore an important additional source of information on the use of the Meuse and the land alongside it in the past. It was agreed with Consortium Grensmaas, which commissions the archaeological watching briefs in the southern Meuse valley, that a representative sample of the broad spectrum of collected iron objects will be described and presented in a catalogue and that the, from an archaeological point of view, most valuable or remarkable examples will be preserved.

\section{New knowledge}

\section{- Introduction}

The archaeological research performed in connection with the Maaswerken project has greatly increased our knowledge of the

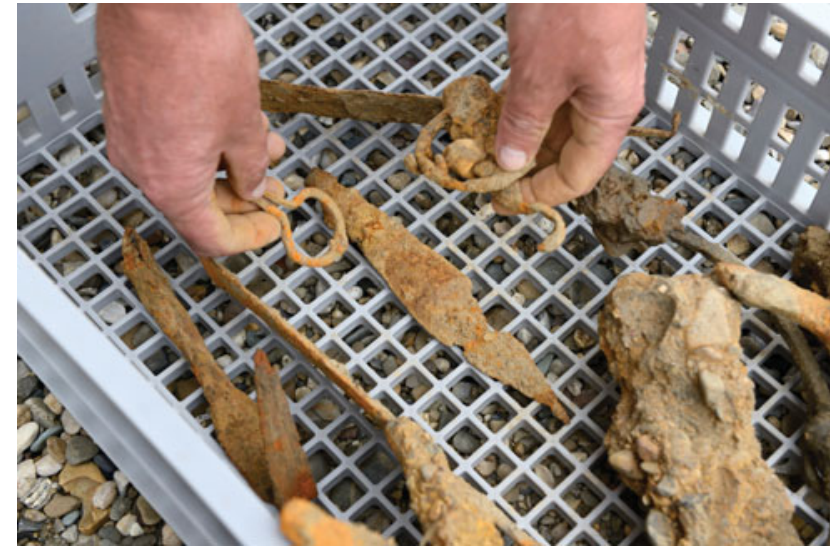

Fig. 3. Inspection of container with (fragments of) iron objects filtered from the gravel processed at the sieving installations at Itteren, summer 2014 (photo: RCE).

geological and pedological properties of the Holocene Meuse valley. The project areas investigated consist of landscapes and deposits from the Holocene (river valley bottom) with, in most areas (e.g. Borgharen, Lomm and Well-Aijen), underlying and/or flanking deposits from the Late Glacial (mainly terrace gullies, ridges and plains from the Late Dryas stadial; see Isarin et al., 2014, in press). They were created over a period of $c$. 15,000 years during which major changes occurred in the climate and, partly as a result of this, the flow behaviour of the 
Meuse changed, from a braided river to a meandering river, and from a river depositing sediment to a river incising into its own sediment. The project areas in the southern Meuse valley, in particular, form part of an extensive and (by Dutch standards) high-relief river terrace landscape formed by the Meuse in the course of the Pleistocene.

In the Early Holocene a river valley several metres deep developed into a floodplain with point bar ridges and levees. It has been found that the structure of the Holocene valley bottom of the Meuse is much more varied and complex than the geological, pedological and geomorphological maps (scale $1: 50,000$ ) of the area suggest. During the Holocene the bed of the Meuse shifted several times, the river depositing different types of sediments under changing climatological conditions, over only short distances. From an archaeological perspective, the important fact is that during this dynamic process former living floors (occupation layers) were either eroded or covered by and embedded into fine-grained river deposits. The Meuse cleared away parts of prehistoric and early historic landscapes, including the archaeological features and remains in them, particularly in the zone immediately adjacent to its current channel. To the north of Itteren, for example, in the western part of the project area of the same name, a thick layer of 'young river clay' has been deposited over the past few centuries (Polman \& Rensink, 2000). During periods of little or no erosion and sedimentation, soil formation took place. Concrete evidence of this in the southern Meuse valley comes in the form of a generally dark-grey, slightly to moderately humic vegetation horizon covered by sediments. This layer has been interpreted as a vegetation horizon, which may have formed at the transition from the Boreal to the Atlantic (see e.g. Meurkens \& Tol, 2011: 45-49; Van de Graaf \& Hermsen, 2013).

As a result of the dynamic impact of the Meuse in terms of erosion and sedimentation, it is difficult to make palaeogeographical reconstructions of specific 'time slices' of the Holocene Meuse valley, particularly compared with the geologically more stable Pleistocene coversand landscapes on either side of the valley. For example, our picture of the landscape and occupation in early prehistory (Mesolithic and Neolithic) is far from complete, as a result not only of erosion but also of the sometimes deep location of preserved Early and Middle Holocene deposits (for Borgharen, see Hermsen, 2013). It should be noted in this connection that Early and Middle Holocene sediment-filled gullies can be hidden in the subsurface, including in places where the current surface has a relatively high elevation (e.g. Borgharen: Koeman, 2013; Lomm phase 2: Gerrets \& De Leeuwe 2011).

\section{Landscape genesis versus occupation and land use history}

Given the age of the sediments found in the project areas, there is no likelihood of finding Middle Palaeolithic sites in situ. Remains of camps and/or archaeological evidence of short-term activity from the later phase of the Late Palaeolithic (Ahrensburg culture) might in theory be located on the Late Dryas terrace, though none has been found to date. Stone artefacts were gathered on gravel-rich terrace deposits from the Late Dryas and on Early Holocene river clay during surface mapping, but these artefacts were scattered and date from later periods. The oldest sites investigated by excavation date from the Early Mesolithic. At Borgharen a unique Early Mesolithic site (site 8) was unexpectedly found beside a former gully (De Grooth, 2013) as a 'chance find' during the excavation of a burial ground with Late Roman and Early Medieval graves (site 6) (Panhuysen et al., 2013). The stone artefacts were found over an area measuring c. $30 \times 25 \mathrm{~m}$ in a fine silty loam layer, at a depth of $80-$ $110 \mathrm{~cm}$ below the current surface. This might be a relatively small 'sediment pocket' formed in unique preservation conditions. Such sediment-covered sites with occupation traces from the Mesolithic have rarely been found in the Holocene river landscapes of the Netherlands, so they are very important for enhancing our knowledge of the settlement system and land use in the vicinity of rivers in the period in question. The site at Borgharen shows that Early Mesolithic hunters and gatherers temporarily camped beside current or former gullies of the Meuse in the southern Meuse valley. Much of the knowledge gained from this site comes from a detailed typological and technological description of the stone artefacts and the nature and origins of the materials used in their manufacture (De Grooth 2013: 99-128). Unfortunately, the site was not detected during the borehole survey and could not be fully excavated because of time and money constraints.

New insights into the landscape genesis in the Meuse valley are also very important for explaining the absence of archaeological sites from certain periods. Compared with the Iron Age, and despite the proximity of important Roman occupation centres (Maastricht, Venlo, Cuijk) and villa sites (Borgharen, Buchten, Afferden), Roman occupation traces were particularly scarce in the project areas investigated. The virtual absence of Roman sites, and also of traces that point to Medieval occupation, is probably connected with an increase in the activity of (and flood risk from) the Meuse. Erosion increased in the hinterland from the Roman period and, more especially, from the period of largescale deforestation and the foundation of settlements in the high Middle Ages (from the 11th century AD) onwards. As a result, a thick layer of flood sediment ('young river clay' as it used to be called) was deposited in the Holocene Meuse valley. Given the growing risk of flooding, even the slightly higher terrace remnants in the Holocene valley bottom would probably have become less attractive locations for settlements, so occupation shifted to the higher Pleistocene areas (away from the Holocene valley bottom). The large number of Roman sites on Pleistocene terrace edges further from the Meuse is clear evidence of this change in location choice. Nevertheless, some Roman sites were found during the Maaswerken investigations, including at WellAijen, section 1 (sites A and D; Ter Wal \& Tebbens, 2012). 
The shift in location choice described above does not entirely hold true for Roman period burials. The late prehistoric burial ground at Lomm, phase 2, includes graves ranging from the Middle Iron Age to the second century AD, which suggests continuity of use (Gerrets \& De Leeuwe, 2011). The excavation of the Emmaus 1 site at Itteren revealed two burial grounds: one that was found to date from the Late Iron Age and the other from the Middle Roman period (Meurkens \& Tol, 2011).

0ccupation traces from the Medieval Period and the 16th and 17th centuries are also rare in the Holocene valley bottom of the Meuse. There are some stone houses, like the Haertelstein homestead at Itteren and Huis De Hildert in Well-Aijen, one of the few indications that in this period people lived in the areas under investigation. At Haertelstein archaeological features and remains were found that are probably associated with use of the homestead in and after the Medieval Period (Van de Graaf, 2009). One notable, fairly frequent phenomenon related to economic activity is the charcoal kilns from the Early and High Medieval Period, like those found at Borgharen (site 11; Van de Graaf, 2013; Van de Graaf \& Loonen, 2013), Lomm phase 2 (Gerrets \& De Leeuwe, 2011) and Well-Aijen, section 4 (Bouma \& Müller, 2014). They are a common phenomenon found spread across various parts of the project areas that were investigated. There is also evidence of iron production in the Early Medieval Period at Well-Aijen, section 4, and an 18th- to 19thcentury field oven was found in the Aan de Maas project area (site 42, De Winter, 2004). Numerous, wide-ranging phenomena are associated with the economy and infrastructure, including traces of iron production, cart tracks, ditches and arable layers, and with battlefield archaeology, including Second World War trenches.

\section{Landscape genesis and features of the archaeological record}

The distance from landscape zones to the (then) Meuse, and the relative elevation of these zones, were an important factor determining whether Late Glacial and/or Early Holocene river sediments were inundated and covered with flood sediments. Whether this happened had major implications for the formation of the archaeological record and how it manifests itself today. The distinction between 'stable' and 'dynamic' landscape zones is highly significant in this connection, in terms of both geomorphological and taphonomic processes and the use of these landscape zones by humans through time.

On the one hand, there are extensive contiguous zones where gravel-rich terrace deposits from the Late Dryas stadial or river clay soils from the Early Holocene lie at or near the current surface. They constitute the higher parts of the Holocene valley bottom of the Meuse, sometimes as the remnants of terraces, or the higher grounds (including terrace edges from the Late Dryas stadial) adjacent to this valley bottom. Since little or no sediment was deposited on them later in the Holocene, the surface served as the living floor of numerous generations of people over many millennia. As a result, we find traces of human activity in the past jumbled together and forming part of a single archaeological level (palimpsest). As such, archaeological remains occur on or just below the current surface. 'Stable' landscape forms have been found at Borgharen (Pasestraat, water abstraction area), Itteren (Emmaus 1 and 2, Voulwames), Koeweide-Trierveld (site 55) and Well-Aijen (sections 3 and 4). These are project areas (or parts of project areas) situated at a relatively large distance from the current bed of the Meuse. One is struck by the fact that the majority of the archaeological sites excavated there date from the Iron Age. Since there are no covering sediments, there is every chance that the original living floor eroded, and archaeological features have been truncated. There is also a possibility that bioturbation has caused a large degree of disturbance. Land use in the historic period led to further deterioration and incorporation of archaeological remains into the ploughsoil (e.g. Itteren Emmaus, Meurkens, Tol, 2011).

On the other hand there are geologically dynamic zones where the Meuse repeatedly deposited fine-grained sediments during the Holocene. These locations sometimes have two or more stratigraphically distinct archaeological levels, with embedded and well-preserved archaeological features and remains. The Early and Middle Holocene point bar ridge at Well-Aijen, section 2, to the north of Venlo in the Zandmaas area is the most evident and striking example of this (Kimenai \& Mooren, 2014). There, the gradual accumulation of a large point bar ridge from the beginning of the Holocene occurred simultaneously with repeated use of the ridge by hunters and gatherers in the Mesolithic. Three or four Mesolithic archaeological levels and, in the top of the point bar ridge, an overlying Neolithic layer were identified in the layer of fine-grained flood sediments (= point bar ridge). The gradual shifting of the Meuse towards the west allowed this point bar ridge to be preserved (unaffected by erosion), despite its position close to the river. The locations consist mainly of small concentrations (c. $5 \mathrm{~m}$ diameter) of stone artefacts, sometimes in spatial association with a surface hearth and/or burnt fragments of hazelnuts. No unburnt organic archaeological remains have been found.

One general feature of Holocene flood sediments from the Meuse, irrespective of whether they are part of 'stable' or 'unstable' landscape forms, is their even brown colour. This colour came about after the sediments in question were deposited and is (probably) the result of bioturbation (homogenisation) in ironrich soils. This process led to blurring and poor (or a complete absence of) recognisability in soil features, particularly in the case of an absence of material remains (pottery, flint) and/or charcoal in the fill. Deeply incised pits and ditches are recognisable as archaeological features only at greater depths, beneath the brown layer, at the top of the Late Dryas terrace, for example. Shallow pits and ditches tend to be entirely indistinguishable as a result of the even brown colour. 


\section{Artefact traps}

One landscape phenomenon of particular significance for the preservation of vulnerable categories of archaeological remains is small, shallow natural depressions in which people deposited waste in the past, or where archaeological remains were secondarily deposited as a result of post-depositional processes. Examples include a depression with pits containing large quantities of Late Roman period find material in the immediate vicinity of a Roman villa at Borgharen (site 5: Van de Graaf, 2013), a depression containing waste that was probably deliberately dumped, near a river dune (dune A3) with occupation traces from the Neolithic, Middle Iron Age and Middle Roman period (site E: Ter Wal \& Tebbens, 2012), and a small depression containing pottery from the Early to Middle Neolithic and other finds at Well-Aijen, section 2 (Kimenai \& Mooren, 2014). From a chronological point of view, this last situation is quite unique. Data on occupation and land use at the time of the transition from the Mesolithic to the Neolithic, and from a way of life based on hunting, gathering and fishing to one where farming and stockbreeding played a central role, are scarce (after the Linear Bandkeramik period in southern Limburg). This is true not only of the Meuse valley in Limburg, but of the entire southeastern Netherlands. Thanks to the fact that the depression acted as an artefact trap, a vulnerable and also rare group of pottery finds was preserved there. This pottery, with elements of the Rössen Culture, or evidence of Rössen influences, can be dated to around the transition from the Early to Middle Neolithic (Mooren et al., 2015).

Outside the depression, a Neolithic find level extends through the top of the point bar ridge, though it contains only a limited number of finds. The Neolithic pottery is also clearly less well preserved than that in the depression. Potsherds collected in the depression therefore provide a very welcome addition to the scarce and fragmentary set of data available on this period in the Holocene Meuse valley. This unique find situation also raises the question of whether the almost complete absence of archaeological remains from the period of the first agrarian societies in the areas investigated as part of the Maaswerken project might point to a hiatus in occupation and land use along the Meuse. The possible role of post-depositional processes such as the weathering of brittle Early and Middle Neolithic pottery, and the possibility that stone artefacts from the Early-Middle Neolithic transition are difficult to identify as such must also be considered.

Locations in both the Grensmaas and Zandmaas areas contain preserved pollen and seeds, providing the potential for vegetation reconstruction. In Well-Aijen, section 4, a borehole made in a former gully of the Meuse revealed a layer of peat dating from the Early Mesolithic to the end of the Early Modern Period (see Zuidhoff \& Bos, 2016). Former Meuse gullies also provide opportunities for archaeobotanical research in the southern Meuse valley, though the results there are more disappointing

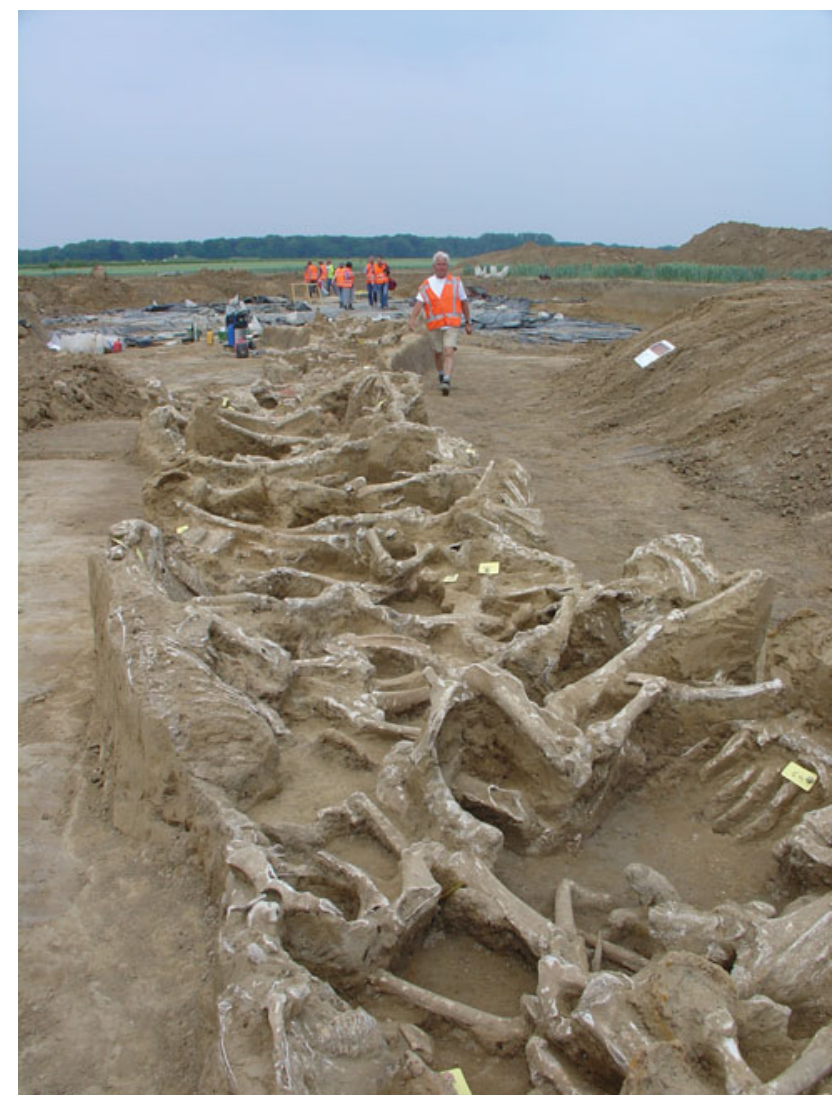

Fig. 4. The unexpected find of a mass horse grave at Borgharen. The grave, containing the skeletons of 65 horses, was fully excavated in summer 2010. The horses were probably killed during one of the sieges of Maastricht in the late 18th century (excavation: Archeodienst; photo: RCE).

due to the poorer state of preservation, as at Borgharen (Koeman, 2013). No layers of peat with potential for archaeobotanical analysis equal to that at Well-Aijen were found at Borgharen and Itteren.

\section{Archaeology of national importance}

The landscape archaeology perspective of the field investigations performed as part of the Maaswerken project produced an extensive and varied set of landscape and archaeological information that would not have been obtained with standard siteoriented investigations. During the course of the project, particularly in the archaeological excavation phase, some conflict arose between the landscape archaeology approach and principles (large areas, no exhaustive documentation of individual sites) and the desire to perform intensive excavation-based investigations of sites of 'national importance'. One clear example of this is the unexpected find of a mass horse grave, probably from the late 18th century, in the Borgharen project area (Loonen \& van de Graaf, 2013; Fig. 4). This find was unique, and made headlines well beyond the Netherlands in the summer of 2010. The horse grave had not been observed during the 


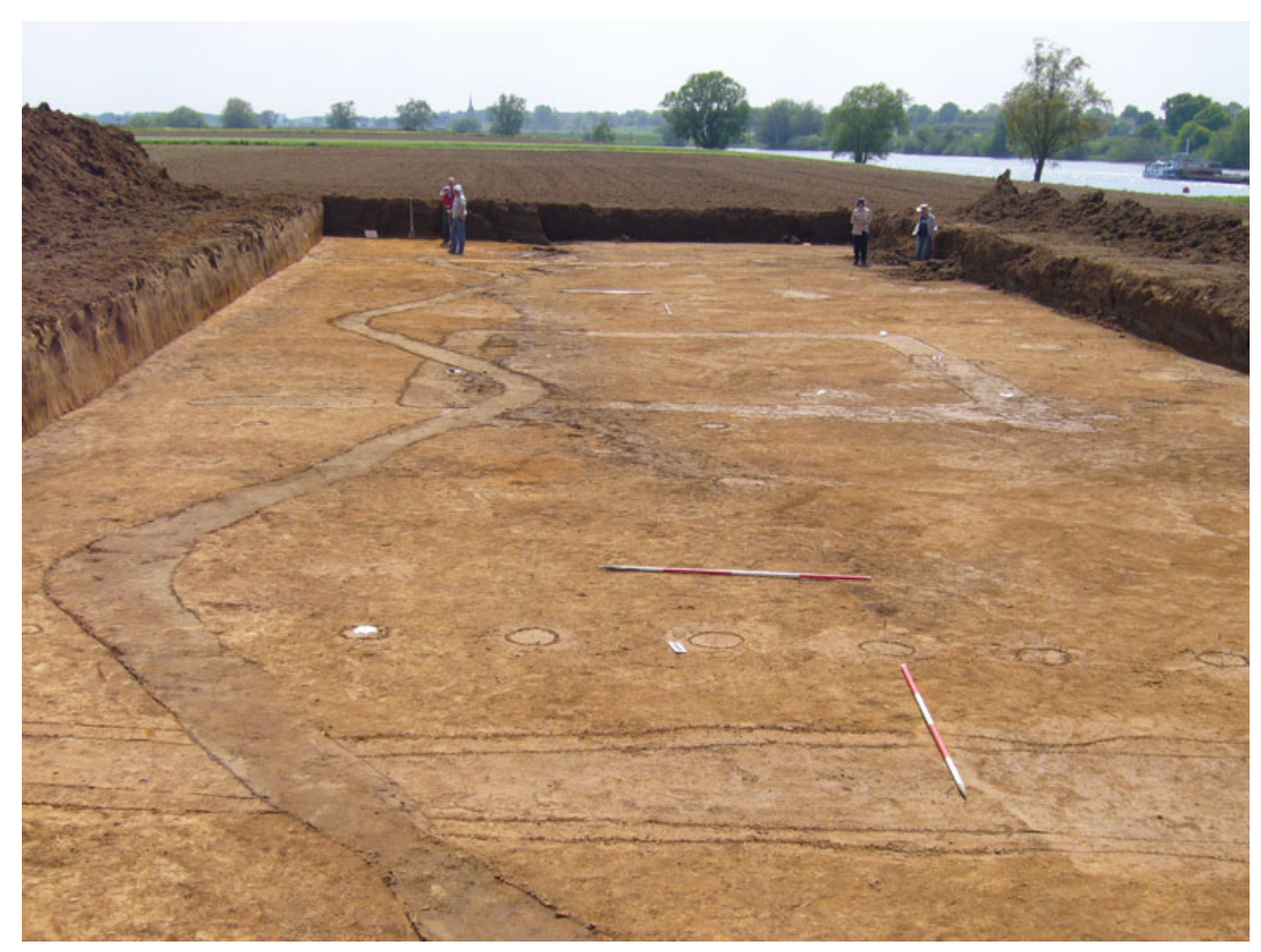

Fig. 5. The 2008 excavation of a cult site and associated burial ground from the fourth century $B C$ to first century $A D$ at Lomm. The cult site includes a large rectangular ditch measuring $38 \times 33.5 \mathrm{~m}$, inside which a second rectangular ditch and traces of small structures were found (excavation: ADC Archeoprojecten; photo: A. Simons, Hazenberg Archeologie).

archaeological field evaluation (borehole survey and trial trench survey). It came to light during the excavation of an area measuring c. 4 ha with late prehistoric occupation traces and graves belonging to an Early Medieval burial ground. The find was therefore entirely unforeseen, and had not been taken into consideration in the time and financial planning. Thanks to the cooperation and financial support of the company carrying out the infrastructural excavation work, Consortium Grensmaas, it was possible to completely excavate and carefully document the mass horse grave. The find highlights the fact that small specific types of sites of major archaeological importance are not always (or often not?) found during archaeological field evaluations.

Another site of national importance is the prehistoric cult site and associated burial ground at Lomm, phase 2. Prehistoric ditches and graves containing cremated human remains and grave gifts were found during the excavation in 2008 (Gerrets \& De Leeuwe, 2011). ${ }^{14} \mathrm{C}$ dating and the grave gifts suggest that the location was used from the Middle Iron Age into the first century $\mathrm{AD}$. The excavated ditches form a rectangle measuring c. $38 \times 33.5 \mathrm{~m}$, within which a second structure of $c .7 \times 8 \mathrm{~m}$ was found (Fig. 5). The ditches surrounded an area where ritual acts were performed. Small wooden buildings and rows of posts were also found at the cult site. The 61 graves consist of small clusters of cremated remains and charcoal, which were probably buried in a cloth. The fully excavated cult site and associated burial ground at Lomm, and a potentially similar ditch structure with cremation burials at Emmaus 1 near Itteren (Meurkens \& Tol, 2011), shed new light on the use of the Holocene valley bottom of the Meuse for burial and ritual purposes from the Middle Iron Age to the Middle Roman period. They provide evidence of the existence of a 'ritual landscape' a stone's throw from the Meuse. Cult sites from late prehistory are very rare in the Netherlands, and have been subjected to very little archaeological investigation. The banks of the Meuse would therefore appear to be very important in this regard.

The final example we would like to mention here, again, is the well-preserved Mesolithic flint concentrations at WellAijen, section 2 (Kimenai \& Mooren, 2014). The find situation is unique in the Netherlands. Never before have archaeological remains from different phases of the Mesolithic and Neolithic been found in fine-grained river sediments, and in separate stratigraphic levels. The results of the 2011-2014 excavations provide a unique opportunity to add to and refine our view of the Mesolithic and the transition from a way of life based on hunting and gathering to arable farming and stockbreeding (Neolithisation process) in the southern Netherlands.

Thanks in part to the experience gained during the archaeological investigations associated with the Maaswerken project, it has become clear that the concept of 'national importance' is 'malleable', and in a certain sense perhaps even an artificial construct. Certain features of the subsurface archaeological resource 
- the occurrence of highly intact, rare archaeological features and remains - are of course important, but they reflect only one side of the coin. The research questions archaeologists use as a basis to explore our buried history, and the way in which it is documented (in terms of fieldwork and interpretation methods and techniques) are the other side. Together, they determine whether the outcomes of archaeological research are of national importance. It is in light of this knowledge that existing project briefs have been extended to include new research questions and new principles and requirements concerning fieldwork methods and techniques. Those performing the archaeological fieldwork ensured that the reports on those investigations were detailed and of a very high standard (see e.g. Gerrets \& De Leeuwe, 2011; Gerrets \& Williams, 2011; Loonen \& Van de Graaf, 2013).

\section{Synthesis of new knowledge}

Thanks to the Maaswerken projects, new knowledge of the past landscape and archaeology of the Holocene Meuse valley in Limburg at area and site level has been acquired and published in the form of standard reports. However, the knowledge is fragmented. There are three reasons for this: (1) the long duration of the Maaswerken project, and therefore also of the archaeological investigations (1995-2015), (2) the geographical spread of the project areas investigated, in southern, central and northern Limburg (from Maastricht in the south to Aijen in the north) and (3) the fact that fieldwork was performed by several different archaeological agencies. This fragmentation means that it is not currently possible to interpret all the knowledge gained concerning the occupation and land use history of the Meuse, and underlines the importance of synthesising research.

In 2015 the RCE commissioned BAAC BV Archeologie en Bouwhistorie ('s-Hertogenbosch) to catalogue, analyse, synthesise and present the knowledge gained in the archaeological investigations associated with the Maaswerken project (20042013). The study should also focus on the relationship between the occupation and land use history of the Holocene Meuse valley and that of the immediate 'hinterland', i.e. the adjacent terrace levels from the Bølling-Allerød interstadial and the Late Dryas stadial, which often lie several metres higher. The results of these studies will be very important for a broader chronological and geographical perspective on the excavation data from the Holocene Meuse valley itself. The definition of new questions for the National Archaeological Research Agenda (version 2.0), which was published online in April 2016 (http://archeologieinnederland.nl/bronnen-en-kaarten/ nationale-onderzoeksagenda-archeologie-20), is also considered an important part of this brief. Taking account of the timespan of the occupation and use of the Holocene Meuse valley and adjacent marginal zones (from the Early Mesolithic to the end of the Second World War), a description of the knowledge gained from a diachronous perspective is an important element of the commission. The synthesis will be completed in early 2017.

Last but not least, landscape and archaeological data from the Maaswerken project have been combined in a new geomorphogenetic map and a set of new predictive archaeological maps (Isarin et al., 2014, 2015). The maps, commissioned by the RCE and Rijkswaterstaat-Maaswerken, will alert anyone involved in future infrastructural excavation work and other spatial developments in the Meuse valley. If large-scale interventions are planned there, such as the digging of side channels, river bed widening, dike relocation or gravel and sand extraction, the maps will show which landscape zones are most likely to hold archaeological remains. Local authority policymakers can also use the maps to supplement their own policy and predictive maps. For a description of the background information, methods used and map images from the Maas Valley Predictive Archaeological map, see Isarin et al. (in press).

\section{Conclusions}

The most important conclusions to be drawn from the archaeological investigations conducted between 1998 and 2015 in the Maaswerken project areas are:

- The large scale of the project areas and of the planned interventions (non-archaeological excavation work) without the option of preservation in situ of archaeological remains makes landscape archaeological research and the archaeological excavation of landscape zones (or contiguous sections of such zones) both possible and desirable. A broad, area-based research perspective is preferable to the site-based 'funnel model', whereby the focus gradually narrows to one particular spot, as specified in the Dutch Archaeology Quality Standard.

- The numerous boreholes made in the late 1990s and the early years of this century yielded a large amount of archaeological material. However, borehole surveys proved a less valuable way of identifying, defining and evaluating individual sites in the Holocene river valley bottom of the Meuse than originally thought at the start of the Maaswerken projects.

- Flexible use of fieldwork methods and flexibility in decisionmaking - including in the excavation research phase - are needed to address research questions adequately and to make the right choice of locations and zones for archaeological excavation.

- The phased approach to archaeological excavation, including the deselection of areas on the basis of progressive insights gained during the fieldwork, was found to be both workable and useful.

- The likelihood of encountering well-preserved, valuable archaeological features and remains is greater in Holocene sedimentation areas with 'dynamic surfaces' than in areas with 'stable surfaces. At Well-Aijen, section 2 the formation of 
an Early Holocene point bar ridge consisting of fine-grained Meuse flood sediments occurred more or less synchronously with human occupation and/or use of the ridge in various phases of the Mesolithic.

- Large-scale excavations led to the discovery of sites of 'national importance' at Borgharen and Lomm that had not been identified during the archaeological field evaluation or borehole survey. Intensive site-oriented investigation of these locations is very important, not only from the point of view of the knowledge to be gained, but also for the purposes of publicity and generating public support. In particular, the find of the horse grave at Borgharen has made clear that in the future, at the start of large infrastructural projects like the Maaswerken project, sufficient funding should be reserved for addressing (excavating) unforeseen, high-quality sites.

\section{Acknowledgements}

The author thanks Sue McDonnell (Utrecht) for translating the Dutch text into English, and the reviewers for their constructive and useful comments on this paper.

\section{References}

Bouma, N. \& Müller, A. (eds), 2014. Tienduizend jaar landschaps- en bewoningsgeschiedenis tussen Well en Aijen. Een verkennend en waarderend onderzoek in de deelgebieden 1 en 4 en een archeologische opgraving in deelgebied 2 te Well-Aijen Hoogwatergeul werkvak 4. ADC-Rapport 3472 (Amersfoort).

Deeben, J., de Grooth, M.E.T., de Kort, J.W., Lauwerier, R.C.G.M. \& ter Schegget, M.E., 2011. Archeologisch onderzoek in de omgeving van het prehistorische vuursteenmijnveld te Rijckholt-St. Geertruid. Rapportage Archeologische Monumentenzorg 202 (Amersfoort).

De Grooth, M., 2013. Vuursteenvindplaats (vindplaats 8). In: van de Graaf, W.-S. \& Loonen, A.F. (eds): Archeologisch onderzoek in het plangebied DaalderveldPasestraat te Borgharen. Archeodienst Rapport 137 (Zevenaar): 93-141.

De Loecker, D. 2005. Beyond the site: the Saalian archaeological record at Maastricht-Belvédère (the Netherlands). Analecta Praehistorica Leidensia $35 / 36$ (Leiden).

De Loecker, D. \& De Grooth, M., 2003. Behoud en onderzoek van archeologische waarden in het Maasdal in het kader van De Maaswerken en de Via Limburg. Gebiedsprogramma Borgharen/Itteren. Rijkswaterstaat - De Maaswerken (Maastricht).

De Winter, J., 2004. De Maaswerken Archeologie. Inventariserend veldonderzoek -waarderende fase - GrensMaas, Aan de Maas (gemeente Meerssen). Vindplaats 42 en 43. BAAC-rapport 03.125 ('s-Hertogenbosch).

Gerrets, D.A. \& De Leeuwe, $\boldsymbol{R}$. (eds), 2011. Rituelen aan de Maas. Een archeologische opgraving te Lomm, Hoogwatergeul fase II. ADC-Rapport 2333 (Amersfoort).

Gerrets, D.A. \& Williams, G.L. (eds), 2011. Water en vuur. Archeologisch proefsleuvenonderzoek en opgraving te Lomm Hoogwatergeul Fase III. ADC-Rapport 2703 (Amersfoort).
Hermsen, I. 2013. Conclusie. In: van de Graaf, W-S. \& Loonen, A.F. (eds): Archeologisch onderzoek in het plangebied Daalderveld-Pasestraat te Borgharen. Archeodienst Rapport 137 (Zevenaar): 389-431.

Isarin, R., Ellenkamp, R., Heunks, E., de Kramer, J., Paulussen, R., Tebbens, L. \& Zuidhoff, F., 2014. Verantwoording methodiek en kaartbeeld van de Geomorfogenetische Kaart van het Maassal (GKM). Rijksdienst voor het Cultureel Erfgoed (Amersfoort).

Isarin, R., Rensink, E., Ellenkamp, R. \& Heunks, E., 2015. Archeologische verwachtingskaart Maasdal tussen Mook en Eijsden. Rijksdienst voor het Cultureel Erfgoed (Amersfoort).

Isarin, R.F.B., Rensink, E., Ellenkamp, G.R. \& Heunks, E., in press. Of Meuse and Man: geomorphogenetic and archaeological predictive maps of the Dutch Meuse Valley. Netherlands Journal of Geosciences / Geologie en Mijnbouw, this issue.

Jeneson, C.F., 2013. Exploring the Roman villa world between Tongres and Cologne. A landscape archaeological approach. Vrije Universiteit Amsterdam (Amsterdam).

Kimenai, P. \& Mooren, J.R., 2014. Steentijdsites langs de Maas. Hoogwatergeul Well-Aijen, Werkvak 2, Inventariserend Veldonderzoek. BAAC-Rapport A-10.0340 ('s-Hertogenbosch).

Koeman, S. 2013. Resultaten fysische geografie. In: van de Graaf, W-S. \& Loonen, A.F. (eds): Archeologisch onderzoek in het plangebied Daalderveld-Pasestraat te Borgharen. Archeodienst Rapport 137 (Zevenaar): 53-80.

Loonen, A. \& van de Graaf, W.-S., 2013. Het massapaardengraf van Borgharen. Archeodienst Rapport 558 (Zevenaar).

Meurkens, L. \& Tol, A.J., 2011. Grafvelden en greppelstructuren uit de ijzertijd en Romeinse tijd bij Itteren (gemeente Maastricht). Opgraving Itteren-Emmaus vindplaatsen 1 \& 2. Archol Rapport 144 (Leiden).

Mooren, J.R., Drenth, E., Tebbens, L.A. \& Müller, A., 2015. A Neolithic settlement from the second half of the fifth millennium cal BC at Well-Aijen (prov. of Limburg, the Netherlands) - an interim report. In: Kabaciński, J., Hartz, S., Raemaekers, D.C.M. \& Terberger, T. (eds): The Dąbki Site in Pomerania and the Neolithisation of the North European Lowlands (c. 5000-3000 cal BC). Archaeology and History of the Baltic 8. Verlag Marie Reidorf GmbH (Rahden): 359-366.

Panhuysen, R., Smits, L. \& Hermsen, I., 2013. Laat-Romeinse en vroegmiddeleeuwse graven (vindplaats 6). In: van de Graaf, W-S. \& Loonen, A.F. (eds): Archeologisch onderzoek in het plangebied DaalderveldPasestraat te Borgharen. Archeodienst Rapport 137 (Zevenaar): 199-263.

Polman, S.P. \& Rensink, E., 2000. Project Grensmaas, deelgebied Itteren: Aanvullende Archeologische Inventarisatie (AAI fase 2). RAAP-Rapport 456 (Amsterdam).

Rademakers, P.C.M., 1998. De prehistorische vuursteenmijnen van Ryckholt-St. Geertruid. Nederlandse Geologische Vereniging, Afd. Limburg (Heerlen).

Raemaekers, D.C.M. \& Heunks, E., 2000. Project Zandmaas, deelgebied Lomm; een Aanvullende Archeologische Inventarisatie (AAI). RAAP-Rapport 499 (Amsterdam).

Rensink, E. \& Vreenegoor, E., 2007. Archeologisch onderzoek op grote schaal. Archeobrief 11: 26-31.

Roebroeks, W.R., 1988. From find scatters to early hominid behaviour: a study of Middle Palaeolithic riverside settlements at Maastricht-Belvédère (the Netherlands). Analecta Praehistorica Leidensia 21 (Leiden). 


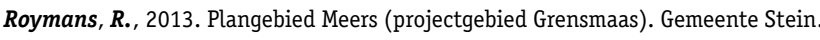
Archeologisch onderzoek: een archeologische begeleiding van de graafwerkzaamheden. RAAP-Notitie 4597 (Amsterdam).

Stoepker, H. (ed.), 2006a. Archeologie in de Maaswerken. Synthese en evaluatie van het inventariserend archeologisch onderzoek in de Maaswerken 1998 2005. Rijkswaterstaat - De Maaswerken (Maastricht).

Stoepker, H., 2006b. Risk control, knowledge acquisition and quality management in an archaeological project: an evaluation of the organisation and the results of the Maaswerken field evaluation, 1998-2005. Berichten van de Rijksdienst voor het Oudheidkundig Bodemonderzoek 46 (Amersfoort), 69-90.

Stoepker, H. \& Soeters, G., 2005. Archaeological heritage management in the Dutch Meuse valley: the Maaswerken project. In: Stoepker, H. (ed.): Archaeological heritage management in riverine landscapes: papers held at the session 'Archaeological heritage management in riverine landscapes', 9 September 2004, 10th annual meeting of the European Association of Archaeologists, Lyon. Rapportage Archeologische Monumentenzorg 126 (Amersfoort): 25-42.

Stoepker, H., Rensink, E. \& Drenth, E., 2004. Behoud en onderzoek van archeologische waarden in het Maasdal in het kader van De Maaswerken en de Via Limburg. Wetenschappelijk beleidsplan 2002. Rapportage Archeologische Monumentenzorg 111 (Amersfoort).

Ter Wal, A. \& Tebbens, L.A., 2012. Hoogwatergeul Well-Aijen, werkvak 1. Archeologische opgraving. BAAC-Report A-09.0395 ('s-Hertogenbosch).

Tichelman, G., 2005a. Archeologisch onderzoek in het kader van de Maaswerken: inventariserend veldonderzoek (IV0), waarderende fase, Koeweide Klein-Trierveld, vindplaatsen 44, 46-47 en 55. ADC-rapport 306 (Amersfoort).

Tichelman, G., 2005b. Archeologisch onderzoek in het kader van de Maaswerken: inventariserend veldonderzoek, waarderende fase Well-Aijen. ADC-report 404 (Amersfoort).
Van de Graaf, W.-S., 2009. Een kasteelhoeve, een baksteenoven en twee prehistorische sites. Een proefsleuvenonderzoek in Itteren-Haertelstein (gemeente Maastricht). Rapport Becker \& Van de Graaf (Zevenaar).

Van de Graaf, W.-S., 2013. Depressie met kuilen (vindplaats 5). In: van de Graaf, W-S. \& Loonen, A.F. (eds): Archeologisch onderzoek in het plangebied Daalderveld-Pasestraat te Borgharen, Archeodienst Rapport 137 (Zevenaar): 264-269.

Van de Graaf, W.-S. \& de Kramer, J., 2005a. Archeologisch Onderzoek in de Maaswerken. Inventariserend Veldonderzoek Borgharen-Daalderveld waarderende fase. Rapport Becker \& Van de Graaf (Nijmegen).

Van de Graaf, W.-S. \& de Kramer, J., 2005b. Archeologisch Onderzoek in de Maaswerken. Inventariserend Veldonderzoek Itteren, waarderende fase. Rapport Becker \& Van de Graaf (Nijmegen).

Van de Graaf, W-S. \& Hermsen, I., 2013. Archeologisch onderzoek in het plangebied Voulwames te Itteren. Archeodienst Rapport 136 (Zevenaar).

Van de Graaf, W-S. \& Loonen, A.F. (eds), 2013. Archeologisch onderzoek in het plangebied Daalderveld-Pasestraat te Borgharen, Archeodienst Rapport 137 (Zevenaar).

Van der Gaauw, P. \& Stassen, P., 2006. Kaartencatalogus van de 'natte' archeologische aandachtsgebieden in het winterbed van de Grensmaas. Rijkswaterstaat - De Maaswerken (Maastricht).

Van Dijk, X.C.C., 2003. Project Zandmaas, deelgebied Well-Aijen; een Aanvullende Archeologische Inventarisatie (AAI). RAAP-Rapport 799 (Amsterdam).

Van Wijk, I., Amkreutz, L.W.S.W. \& van de Velde, P., 2014.'Vergeten' Bandkeramiek. Een Odyssee naar de oudste neolithische bewoning in Nederland. Sidestone Press (Leiden).

Zuidhoff, F.S. \& Bos, J.A.A., 2016. Sedimentation and vegetation history of a buried Meuse terrace during the Holocene in relation to the human occupation history (Limburg, the Netherlands). Netherlands Journal of Geosciences / Geologie en Mijnbouw, DOI: https://doi.org/10.1017/njg.2016.43. Published online 7 December 2016. 